\title{
Anoxybacillus ayderensis sp. nov. and Anoxybacillus kestanbolensis sp. nov.
}

Correspondence

Ali Osman Belduz

belduz@ktu.edu.tr
Sabriye Dulger, Zihni Demirbag and Ali Osman Belduz

Karadeniz Technical University, Faculty of Arts and Sciences, Department of Biology, 61080 Trabzon, Turkey

Two thermophilic bacilli were isolated from mud and water samples of the Ayder and Kestanbol hot springs in the provinces of Rize and Canakkale, respectively, in Turkey. Strains $\mathrm{ABO} 4^{\top}$ and $\mathrm{K} 4^{\top}$ were sporulating, Gram-positive, rod-shaped bacteria. These isolates were moderately thermophilic (with an optimum temperature for growth of $50-55^{\circ} \mathrm{C}$ ), facultative anaerobes able to grow on a wide range of carbon sources including D-glucose, D-raffinose, D-sucrose, D-xylose, $\mathrm{D}$-fructose, L-arabinose, maltose, D-mannose and D-mannitol. Analysis of the 16S rRNA gene sequences showed that these isolates resembled Anoxybacillus flavithermus DSM $2641^{\top}$ and Anoxybacillus gonensis NCIMB $13933^{\top}$. DNA-DNA hybridization data revealed that thermophilic isolate $\mathrm{AB} 04^{\top}$ has only $51 \cdot 2 \%$ relatedness to $A$. flavithermus, $45 \cdot 1 \%$ relatedness to Anoxybacillus pushchinoensis and $68.6 \%$ relatedness to $A$. gonensis. Thermophilic isolate $\mathrm{K} 4{ }^{\top}$ showed only $60.4 \%$ relatedness to $A$. flavithermus, $42.9 \%$ relatedness to $A$. pushchinoensis and $38.5 \%$ relatedness to $A$. gonensis. On the basis of the DNA-DNA hybridization data, isolates $\mathrm{ABO} 4^{\top}$ and $\mathrm{K} 4^{\top}$ are not related to A. flavithermus DSM $2641^{\top}$, A. pushchinoensis DSM $12423^{\top}$ or $A$. gonensis NCIMB $13933^{\top}$ at the species level, but show relatedness to one another of $40.5 \%$. On the basis of the data presented, it is proposed that strains $\mathrm{ABO} 4^{\top}(=\mathrm{NCIMB}$ $13972^{\top}=$ NCCB $\left.100050^{\top}\right)$ and $\mathrm{K} 4^{\top}\left(=\operatorname{NCIMB~} 13971^{\top}=\right.$ NCCB $\left.100051^{\top}\right)$ be designated as the type strains of Anoxybacillus ayderensis sp. nov. and Anoxybacillus kestanbolensis sp. nov., respectively.
The genus Anoxybacillus is separate from the genus Bacillus, and the type species is Anoxybacillus pushchinoensis DSM $12423^{\mathrm{T}}$ (Pikuta et al., 2000). Pikuta et al. (2000) first described the type species of the genus as an obligate anaerobe. Later, Pikuta et al. (2003) corrected the description of the species $A$. pushchinoensis from 'obligate anaerobe' to 'aerotolerant anaerobe' and also changed the description of the genus Anoxybacillus from one comprising obligate anaerobes to facultative anaerobes to one comprising aerotolerant anaerobes or facultative anaerobes. At the time of writing, the genus Anoxybacillus contained three species: Anoxybacillus flavithermus, A. pushchinoensis Pikuta et al. 2000 and Anoxybacillus gonensis Belduz et al. 2003.

The present paper describes the isolation, morphology, biochemical profile, 16S rRNA gene sequence and results of DNA-DNA hybridization with close relatives of two facultatively anaerobic, moderately thermophilic, facultatively alkaliphilic isolates that represent novel species of the

Published online ahead of print on 20 February 2004 as DOI 10.1099/ ijs.0.02863-0.

The GenBank accession numbers for the 16S rRNA gene sequences of strains $\mathrm{ABO}^{\top}$ and $\mathrm{K} 4^{\top}$ are AF001963 and $\mathrm{AY} 248711$. genus Anoxybacillus. Strain $\mathrm{AB} 04^{\mathrm{T}}$ (pH range 6.0-11.0) is proposed as the type strain of Anoxybacillus ayderensis sp. nov. Strain $\mathrm{K}^{\mathrm{T}}$ ( $\mathrm{pH}$ range $\left.6 \cdot 0-10 \cdot 5\right)$ is proposed as the type strain of Anoxybacillus kestanbolensis sp. nov.

\section{Isolation of strains}

Two strains of Gram-positive rods, strains $\mathrm{AB} 04^{\mathrm{T}}$ and $\mathrm{K} 4^{\mathrm{T}}$, were isolated from mud and water samples of the Ayder and Kestanbol hot springs in the provinces of Rize and Canakkale, respectively, in Turkey. The water temperature of these hot springs is around $60-70{ }^{\circ} \mathrm{C}$. After collection, mud and water samples were immediately used for enrichment in nutrient broth (NB) at $60-70{ }^{\circ} \mathrm{C}$. One-dayold enrichment cultures were repeatedly subcultured in $10 \mathrm{ml} \mathrm{NB}$ and streaked on agar plates to obtain separate colonies. The purity of the isolates was assessed by using colony morphology and microscopy. After 48 h growth on nutrient agar medium, colonies of strain $\mathrm{AB} 04^{\mathrm{T}}$ were 1-2 $\mathrm{mm}$ in diameter, cream, regular in shape with round edges. Colonies of strain $\mathrm{K} 4^{\mathrm{T}}$ were the same except that they were $1-2.5 \mathrm{~mm}$ in diameter. Light microscopy revealed that cells of strains $\mathrm{AB} 04^{\mathrm{T}}$ and $\mathrm{K} 4^{\mathrm{T}}$ were motile and were, respectively, $0.55 \times 4.60 \mu \mathrm{m}$ and $0.65 \times 4.75 \mu \mathrm{m}$ in size. 


\section{Biochemical and nutritional characteristics}

The utilization of organic compounds as sole carbon sources was tested in basal medium $(5 \mathrm{ml})$ supplemented with $0.5 \%(\mathrm{w} / \mathrm{v})$ concentrations of the following compounds (which had been separately sterilized as stock solutions): D-glucose, D-mannitol, D-mannose, D-sucrose, D-xylose, L-arabinose, D-fructose, lactose, D-raffinose, starch and L-rhamnose. Incubation was carried out at $60^{\circ} \mathrm{C}$. Strains $\mathrm{AB} 04^{\mathrm{T}}$ and $\mathrm{K} 4^{\mathrm{T}}$ were nutritionally versatile and used a wide variety of carbohydrates when grown on basal medium. Strain $\mathrm{AB} 04^{\mathrm{T}}$ grew on D-glucose, D-raffinose, D-sucrose, D-xylose, D-fructose, L-arabinose, maltose and D-mannose, while strain $\mathrm{K}^{\mathrm{T}}$ grew on D-mannitol, Dglucose, D-fructose, maltose, D-mannose, D-raffinose and D-sucrose (Table 1). Anaerobic growth was tested in anaerobic agar medium. Strains $\mathrm{AB} 04^{\mathrm{T}}$ and $\mathrm{K} 4^{\mathrm{T}}$ grew well aerobically but are facultatively anaerobic bacteria. Strain $\mathrm{K} 4^{\mathrm{T}}$ grew well on anaerobic agar medium without yeast extract but strain $\mathrm{AB} 04^{\mathrm{T}}$ grew on anaerobic agar medium only when supplemented with yeast extract.

The temperature range for growth $\left(30-75^{\circ} \mathrm{C}\right)$ and the $\mathrm{pH}$ range for growth $(5 \cdot 0-11 \cdot 0)$ were determined in NB medium. Media were adjusted to the initial $\mathrm{pH}$ indicated with either $1 \mathrm{M} \mathrm{NaOH}$ or $1 \mathrm{M} \mathrm{HCl}$. Strain $\mathrm{AB} 04^{\mathrm{T}}$ grew well at $30-70{ }^{\circ} \mathrm{C}$, with optimum growth at $50{ }^{\circ} \mathrm{C}$, and grew well at $\mathrm{pH} 6 \cdot 0-11 \cdot 0$, with optimum growth at $7 \cdot 5-8 \cdot 5$.
Strain $\mathrm{K} 4^{\mathrm{T}}$ grew well at $40-70{ }^{\circ} \mathrm{C}$, with optimum growth at $50-55^{\circ} \mathrm{C}$, and grew well at $\mathrm{pH} 6 \cdot 0-10 \cdot 5$, with optimum growth at $\mathrm{pH} 7 \cdot 5-8 \cdot 5$. Catalase and oxidase were detected by using the method of Cowan \& Steel (1974); strains $\mathrm{AB} 04^{\mathrm{T}}$ and $\mathrm{K} 4^{\mathrm{T}}$ were catalase- and oxidase-positive.

\section{Salt and antibiotic sensitivity}

Four sets of $\mathrm{NB}$ were prepared containing $\mathrm{NaCl}$ at $1,1 \cdot 5$, $2,2 \cdot 5,3,4,5$ and $7 \%$. The growth of the isolates at different salt concentrations was tested using $\mathrm{NB}$ as organic substrate and a control broth without any $\mathrm{NaCl}$ supplementation. Growth of strain $\mathrm{AB} 04^{\mathrm{T}}$ and growth of strain $\mathrm{K}^{\mathrm{T}}$ were inhibited in the presence of $\mathrm{NaCl}$ concentrations above $2 \cdot 5$ and $4.0 \%$, respectively, and in the presence of ampicillin $\left(25 \mu \mathrm{g} \mathrm{ml}^{-1}\right)$, streptomycin sulphate $\left(25 \mu \mathrm{g} \mathrm{ml}^{-1}\right)$, tetracycline $\left(12 \cdot 5 \mu \mathrm{g} \mathrm{ml}^{-1}\right)$, gentamicin $\left(10 \mu \mathrm{g} \mathrm{ml}^{-1}\right)$ and kanamycin $\left(10 \mu \mathrm{g} \mathrm{ml}^{-1}\right)$. The optimal $\mathrm{NaCl}$ concentrations for growth of $\mathrm{AB}^{\mathrm{T}} 4^{\mathrm{T}}$ and $\mathrm{K} 4^{\mathrm{T}}$ were 1.5 and $2 \cdot 5 \%$, respectively.

\section{Spore formation}

The formation of spores was tested for by using microscopic observation of both liquid cultures and single colonies of the isolates from agar plates at different incubation periods. Incubation periods of 1-2 days were required before spore formation became detectable on

Table 1. Physiological and biochemical properties of strains $\mathrm{AB} 04^{\top}$ and $\mathrm{K} 4^{\top}$ and Anoxybacillus type strains

Strains: $1, \mathrm{AB} 04^{\mathrm{T}} ; 2, \mathrm{~K}^{\mathrm{T}} ; 3$, A. gonensis $\mathrm{NCIMB} 13933^{\mathrm{T}} ; 4$, A. flavithermus DSM $2641^{\mathrm{T}} ; 5$, A. pushchinoensis DSM $12423^{\mathrm{T}}$. Cells of both novel taxa are sporulating rods, both novel taxa show anaerobic growth and oxidase activity and both novel taxa are positive for the utilization of starch, D-sucrose, D-glucose and D-fructose. ND, No data available; W, weak growth.

\begin{tabular}{|lccccc|}
\hline Characteristic & $\mathbf{1}$ & $\mathbf{2}$ & $\mathbf{3}$ & $\mathbf{4}$ & $\mathbf{5}$ \\
\hline DNA G+C content (mol\%) & 54 & 50 & 57 & $41 \cdot 6$ & 42 \\
Temperature $\left({ }^{\circ} \mathrm{C}\right)$ for growth: & & & & & \\
$\quad$ Range & $30-70$ & $40-70$ & $40-70$ & $30-72$ & $37-66$ \\
Optimum & 50 & $50-55$ & $55-60$ & $60-65$ & 62 \\
pH for growth: & & & & & \\
Range & $6 \cdot 0-11 \cdot 0$ & $6 \cdot 0-10 \cdot 5$ & $6 \cdot 0-10 \cdot 0$ & $5 \cdot 5-9 \cdot 0$ & $8-10 \cdot 5$ \\
Optimum & $7 \cdot 5-8$ & $7 \cdot 5-8 \cdot 5$ & $7 \cdot 5-8 \cdot 0$ & $7 \cdot 0$ & $9 \cdot 5-9 \cdot 7$ \\
Maximum NaCl concentration for growth $(\%)$ & $2 \cdot 5$ & $4 \cdot 0$ & $4 \cdot 0$ & $2 \cdot 5$ & $3 \cdot 0$ \\
Carbon sources tested (in BM): & & & & & \\
D-Raffinose & + & + & + & - & ND \\
D-Xylose & + & - & + & - & ND \\
L-Arabinose & + & - & - & w & ND \\
D-Mannose & + & + & - & + & ND \\
L-Rhamnose & - & - & - & - & ND \\
D-Mannitol & + & + & + & + & ND \\
Lactose & - & - & - & - & ND \\
Nitrate reduction & - & + & + & - & + \\
Hydrolysis of gelatine & + & - & + & - & - \\
\end{tabular}


agar plates. Light microscopy revealed that strains $\mathrm{AB} 04^{\mathrm{T}}$ and $\mathrm{K} 4^{\mathrm{T}}$ were sporulating bacilli. Cells of strains $\mathrm{AB} 04^{\mathrm{T}}$ and $\mathrm{K} 4^{\mathrm{T}}$ formed terminal, spherical endospores.

\section{SDS-PAGE analysis}

Extraction of proteins from growing cells, measurement of protein concentrations in the extracts, electrophoresis and staining of proteins bands were performed as described previously (Belduz et al., 2003). The electrophoretic patterns of the soluble cellular proteins, as determined by the PAGE method (Fig. 1), showed that $\mathrm{AB} 04^{\mathrm{T}}$ and $\mathrm{K} 4^{\mathrm{T}}$ are not similar to A. flavithermus DSM $2641^{\mathrm{T}}$, A. pushchinoensis DSM $12423^{\mathrm{T}}$, A. gonensis NCIMB $13933^{\mathrm{T}}$ or each other (Fig. 1).

\section{5 rRNA gene sequence analysis}

The 16S rRNA genes were selectively amplified and cloned into the pGEM-T vector system and then the gene sequences were determined and compared with the 16S rRNA gene sequences of some representatives of the Bacillus group, as described previously (Belduz et al., 2003). On the basis of $16 \mathrm{~S}$ rRNA gene sequence analysis, $\mathrm{AB} 04^{\mathrm{T}}$ has more than $98 \%$ similarity to the sequences of A. gonensis NCIMB $13933^{\mathrm{T}}$ and A. flavithermus DSM $2641^{\mathrm{T}}$, and has $97 \%$ similarity to A. pushchinoensis DSM $12423^{\mathrm{T}}$. The $16 \mathrm{~S}$ rRNA gene sequence of $\mathrm{K}^{\mathrm{T}}$ exhibits $97 \%$ similarity to that of A. flavithermus DSM $2641^{\mathrm{T}}$ and more than $96 \%$ sequence similarity to A. gonensis NCIMB $13933^{\mathrm{T}}$ and A. pushchinoensis DSM $12423^{\mathrm{T}}$.

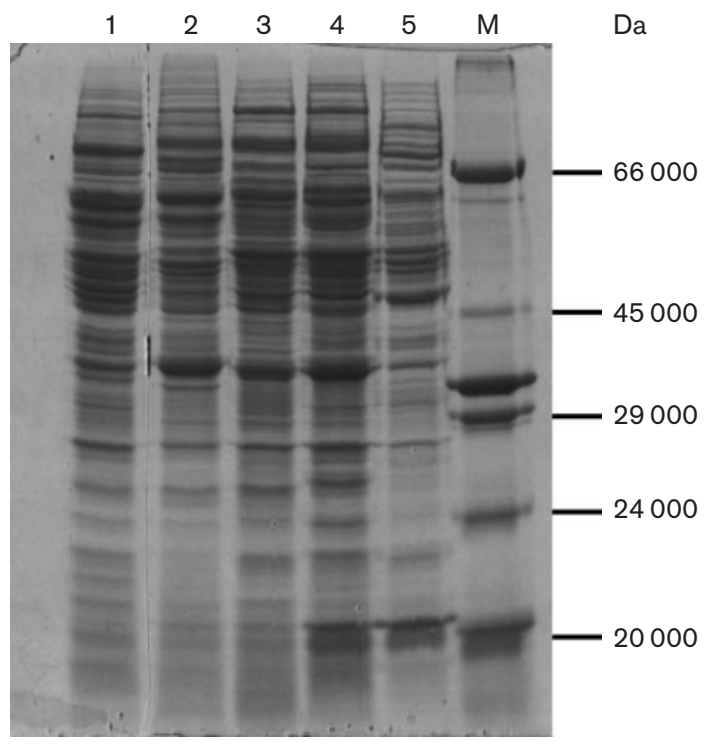

Fig. 1. SDS-PAGE whole-cell protein profiles of $A$. gonensis NCIMB $13933^{\top}$ (lane 1), A. kestanbolensis sp. nov. K4 ${ }^{\top}(2), A$. ayderensis sp. nov. $\mathrm{ABO} 4^{\top}$ (3), A. flavithermus DSM $2641^{\top}$ (4) and $A$. pushchinoensis DSM $12423^{\top}$ (5). Lane M, markers.
16S rRNA gene sequences obtained from the GenBank database were aligned and a neighbour-joining phylogenetic tree was constructed by using DNADIST and NEIGHBOR programs implemented as part of the PHYLIP package (Felsenstein, 1993). Phylogenetic analysis revealed a clustering of $\mathrm{K}^{\mathrm{T}}$ and $\mathrm{AB} 04^{\mathrm{T}}$ in the same branch with other Anoxybacillus species (Fig. 2).

\section{G+C content and DNA-DNA hybridization analyses}

Extraction, purification and determination of the $\mathrm{G}+\mathrm{C}$ content of DNA were performed as described previously (Belduz et al., 2003). The G+C contents of strains AB04 ${ }^{\mathrm{T}}$ and $\mathrm{K} 4^{\mathrm{T}}$ are 54 and $50 \mathrm{~mol} \%$, respectively, which are lower than those of A. flavithermus DSM $2641^{\mathrm{T}}$ and A. gonensis NCIMB $13933^{\mathrm{T}}$.

On the basis of 16S rRNA gene sequence analysis, isolates $\mathrm{AB} 04^{\mathrm{T}}$ and $\mathrm{K} 4^{\mathrm{T}}$ showed $\geqslant 97 \%$ similarity to other Anoxybacillus species; therefore, a DNA-DNA hybridization study was performed among $\mathrm{AB} 04^{\mathrm{T}}, \mathrm{K} 4^{\mathrm{T}}$, Anoxybacillus flavithermus DSM $2641^{\mathrm{T}}$, Anoxybacillus gonensis $\mathrm{NCIMB} 13933^{\mathrm{T}}$ and Anoxybacillus pushchinoensis DSM $12423^{\mathrm{T}}$. Isolation of genomic DNA for DNA-DNA hybridization and determination of DNA-DNA hybridization were performed as described previously (Belduz et al., 2003). DNA-DNA hybridization performed between $\mathrm{AB} 04^{\mathrm{T}}$ and A. gonensis NCIMB $13933^{\mathrm{T}}$ revealed $68.6 \%$ relatedness. However, strain $\mathrm{AB} 04^{\mathrm{T}}$ differs from A. gonensis $\mathrm{NCIMB} 13933^{\mathrm{T}}$ in its growth temperature range and optimum, $\mathrm{pH}$ range and optimum, $\mathrm{NaCl}$ tolerance, reduction of nitrate to nitrite and utilization of some sugars as carbon source. Thermophilic

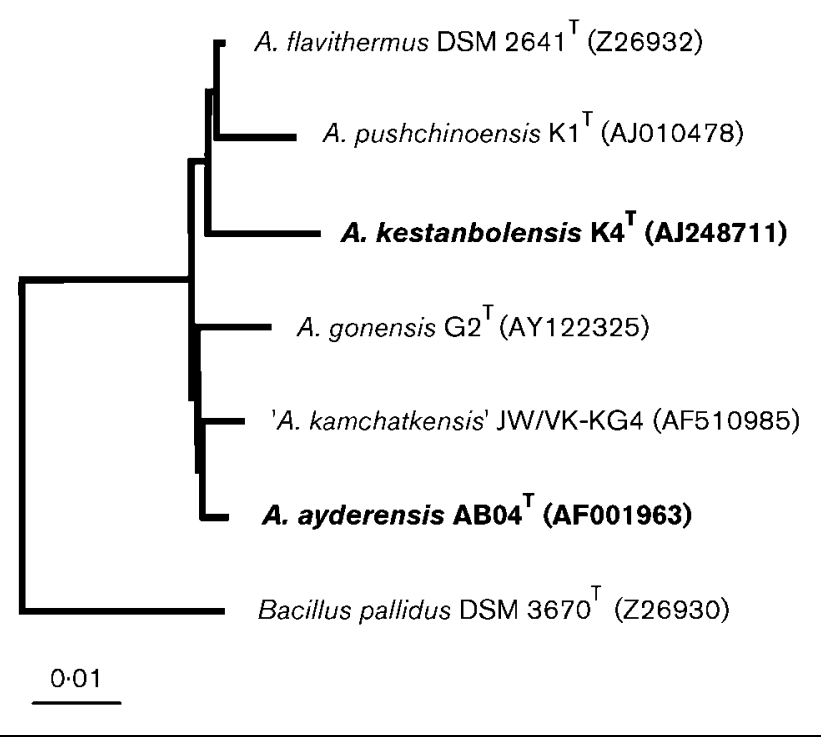

Fig. 2. Phylogenetic relationships of Anoxybacillus species, showing the positions of the novel isolates. Neighbour-joining tree based on 16S rRNA gene sequences. Bar, 1 substitution per 100 nucleotide positions. 
isolate $\mathrm{K} 4^{\mathrm{T}}$ showed similarity to A. flavithermus DSM $2641^{\mathrm{T}}$, but DNA-DNA hybridization performed between $\mathrm{K}^{\mathrm{T}}$ and A. flavithermus DSM $2641^{\mathrm{T}}$ showed only $60 \cdot 4 \%$ relatedness.

As the novel isolates were found to be closely related genetically to A. gonensis NCIMB $13933^{\mathrm{T}}$ and A. flavithermus DSM $2641^{\mathrm{T}}$, we decided that they belong to the genus Anoxybacillus. The genus contains another species, $A$. pushchinoensis. In this study, DNA-DNA hybridization revealed $45 \cdot 1 \%$ DNA-DNA relatedness between $\mathrm{AB} 04^{\mathrm{T}}$ and A. pushchinoensis and $42 \cdot 9 \%$ DNA-DNA relatedness between $\mathrm{K} 4^{\mathrm{T}}$ and $A$. pushchinoensis. On the basis of DNA-DNA hybridization, strains $\mathrm{AB} 04^{\mathrm{T}}$ and $\mathrm{K} 4^{\mathrm{T}}$ show $40 \cdot 5 \%$ relatedness (Table 2). Wayne et al. (1987) suggested that relatedness levels below $70 \%$ indicate that strains belong to different species.

\section{Cellular fatty acids}

Cultivation, harvesting, preparation and analysis of cellular fatty acid methyl esters (FAMEs) from whole-cell fatty acids from strain $\mathrm{AB} 04^{\mathrm{T}}$, strain $\mathrm{K}^{\mathrm{T}}{ }$, A. flavithermus DSM $2641^{\mathrm{T}}$ and A. gonensis NCIMB $13933^{\mathrm{T}}$ were performed using the Sherlock Microbial Identification System, version 4.0, according to the instructions of the manufacturer (MIDI). FAME profiles of strain $\mathrm{AB} 04^{\mathrm{T}}$, strain $\mathrm{K} 4^{\mathrm{T}}$, A. flavithermus DSM $2641^{\mathrm{T}}$ and A. gonensis NCIMB $13933^{\mathrm{T}}$ were identified by comparing the commercial M17H10 database with the MIS software package (version 3.8; Microbial ID) (Table 3). The FAME profiles of $\mathrm{AB} 04^{\mathrm{T}}$ and $\mathrm{K} 4^{\mathrm{T}}$ show that the main fatty acid is $\mathrm{C}_{15: 0}$ iso $(48 \cdot 17$ and $68.62 \%$, respectively); $\mathrm{C}_{15: 0}$ iso is also the main fatty acid in A. gonensis, $A$. pushchinoensis and A. flavithermus. $\mathrm{AB} 04^{\mathrm{T}}, \mathrm{K}^{\mathrm{T}}$, A. flavithermus DSM $2641^{\mathrm{T}}$ and A. gonensis NCIMB $13933^{\mathrm{T}}$ contain $\mathrm{C}_{17: 0}$ iso as a major fatty acid, but $A$. pushchinoensis DSM $12423^{\mathrm{T}}$ differs by having $\mathrm{C}_{16: 0}$ as a major component. This indicates that there are similarities among the FAME profiles of Anoxybacillus species, including strains $\mathrm{AB} 04^{\mathrm{T}}$ and $\mathrm{K}^{\mathrm{T}}$, which also share approximately $\geqslant 97 \% 16 \mathrm{~S}$ rRNA sequence similarity.

On the basis of these data, we suggest that thermophilic isolates $\mathrm{AB} 04^{\mathrm{T}}$ and $\mathrm{K} 4^{\mathrm{T}}$ are not related to A. gonensis NCIMB $13933^{\mathrm{T}}$, A. flavithermus DSM $2641^{\mathrm{T}}$ or A. pushchinoensis DSM $12423^{\mathrm{T}}$ at the species level, and we propose that they be placed in the genus Anoxybacillus as Anoxybacillus ayderensis sp. nov. (strain $\mathrm{AB} 04^{\mathrm{T}}$ ) and Anoxybacillus kestanbolensis sp. nov. (strain $\mathrm{K}^{\mathrm{T}}$ ).

Table 2. DNA-DNA relatedness (\%)

\begin{tabular}{|c|c|c|}
\hline Strain & $\mathrm{K} 4^{\mathrm{T}}$ & $\mathrm{AB04}{ }^{\mathrm{T}}$ \\
\hline $\mathrm{AB} 04^{\mathrm{T}}$ & $40 \cdot 5$ & - \\
\hline A. gonensis NCIMB $13933^{\mathrm{T}}$ & $38 \cdot 5$ & $68 \cdot 6$ \\
\hline A. flavithermus DSM $2641^{\mathrm{T}}$ & $60 \cdot 4$ & $51 \cdot 2$ \\
\hline A. pushchinoensis DSM $12423^{\mathrm{T}}$ & $42 \cdot 9$ & $45 \cdot 1$ \\
\hline
\end{tabular}

Table 3. Fatty acid profiles of strains $\mathrm{ABO} 4^{\top}$ and $\mathrm{K} 4^{\top}$ and Anoxybacillus type strains

Strains: $1, \mathrm{AB}_{0} 4^{\mathrm{T}} ; 2, \mathrm{~K}^{\mathrm{T}} ; 3$, A. gonensis $\mathrm{G}^{\mathrm{T}} ; 4$, A. flavithermus DSM $2641^{\mathrm{T}}$; 5, A. pushchinoensis DSM $12423^{\mathrm{T}}$. Values are percentages of total fatty acids. Data for A. pushchinoensis were taken from Pikuta et al. (2000).

\begin{tabular}{|lccccc|}
\hline Fatty acid & $\mathbf{1}$ & $\mathbf{2}$ & $\mathbf{3}$ & $\mathbf{4}$ & $\mathbf{5}$ \\
\hline $\mathrm{C}_{12: 0}$ & - & - & - & - & $6 \cdot 9$ \\
$\mathrm{C}_{14: 0}$ iso & - & $0 \cdot 88$ & $1 \cdot 25$ & - & - \\
$\mathrm{C}_{14: 0}$ & $1 \cdot 02$ & $1 \cdot 29$ & $1 \cdot 18$ & $1 \cdot 96$ & $7 \cdot 3$ \\
$\mathrm{C}_{15: 0}$ iso & $48 \cdot 17$ & $68 \cdot 62$ & $65 \cdot 19$ & $54 \cdot 85$ & $38 \cdot 7$ \\
$\mathrm{C}_{15: 0}$ anteiso & $3 \cdot 58$ & $3 \cdot 56$ & $2 \cdot 64$ & $4 \cdot 02$ & $2 \cdot 0$ \\
$\mathrm{C}_{15: 0}$ & $0 \cdot 83$ & $1 \cdot 11$ & $1 \cdot 12$ & $1 \cdot 18$ & $0 \cdot 9$ \\
$\mathrm{C}_{16: 0}$ iso & $7 \cdot 47$ & $6 \cdot 37$ & $5 \cdot 99$ & $2 \cdot 97$ & $0 \cdot 3$ \\
$\mathrm{C}_{16: 1}$ & - & - & - & - & $2 \cdot 6$ \\
$\mathrm{C}_{16: 0}$ & $9 \cdot 10$ & $3 \cdot 47$ & $2 \cdot 38$ & $11 \cdot 13$ & $14 \cdot 5$ \\
$\mathrm{C}_{16: 0}$ 10-methyl & - & - & - & - & $0 \cdot 9$ \\
$\mathrm{C}_{17: 1} \omega 5 c$ & - & $0 \cdot 59$ & $2 \cdot 63$ & - & - \\
$\mathrm{C}_{15: 0}$ iso $\mathrm{OH}$ & - & - & - & - & $0 \cdot 3$ \\
$\mathrm{C}_{17: 0}$ anteiso $\mathrm{A}$ & - & - & $0 \cdot 82$ & - & - \\
$\mathrm{C}_{17: 0}$ iso & $20 \cdot 62$ & $9 \cdot 54$ & $11 \cdot 96$ & $17 \cdot 74$ & $0 \cdot 8$ \\
$\mathrm{C}_{17: 0}$ & - & - & - & - & $0 \cdot 5$ \\
$\mathrm{C}_{17: 0}$ anteiso & $9 \cdot 22$ & $3 \cdot 69$ & $3 \cdot 29$ & $6 \cdot 15$ & $0 \cdot 1$ \\
$\mathrm{C}_{18: 2}$ & - & - & - & - & $2 \cdot 2$ \\
$\mathrm{C}_{18: 1 \delta 9}$ & - & - & - & - & $4 \cdot 3$ \\
$\mathrm{C}_{18: 1 \delta 1}$ & - & - & - & - & $1 \cdot 0$ \\
$\mathrm{C}_{18: 0}$ & - & - & - & - & $10 \cdot 4$ \\
$\mathrm{C}_{20: 0}$ & - & - & - & - & $0 \cdot 6$ \\
& & & & & \\
\hline
\end{tabular}

\section{Description of Anoxybacillus ayderensis sp. nov.}

Anoxybacillus ayderensis (ay.de.ren'sis. N.L. masc. adj. ayderensis pertaining to Ayder, a hot spring in the province of Rize, Turkey, where the type strain was isolated).

Cells are Gram-positive, motile, spore-forming rods, $0.55 \times 4.60 \mu \mathrm{m}$ in size. Terminal, spherical endospores are formed. Colonies are $1-2 \mathrm{~mm}$ in diameter, cream, regular in shape with round edges. Catalase- and oxidasepositive. Starch and gelatin are hydrolysed. D-Glucose, D-raffinose, D-sucrose, D-xylose, D-fructose, L-arabinose, maltose and D-mannose are utilized. Nitrate is reduced to nitrite. Urease, indole and $\mathrm{H}_{2} \mathrm{~S}$ are not produced. Growth occurs in the absence of $\mathrm{NaCl}$; optimum growth at $1.5 \% \mathrm{NaCl}$. No growth at concentrations above $2.5 \% \mathrm{NaCl}$. The $\mathrm{pH}$ range for growth is $6 \cdot 0-11 \cdot 0$; optimum $\mathrm{pH}$ is $7 \cdot 5-8 \cdot 5$. Growth is inhibited in the presence of ampicillin $\left(25 \mu \mathrm{g} \mathrm{ml}^{-1}\right)$, streptomycin sulphate $\left(25 \mu \mathrm{g} \mathrm{ml}^{-1}\right)$, tetracycline $\left(12 \cdot 5 \mu \mathrm{g} \mathrm{ml}^{-1}\right)$, gentamicin $\left(10 \mu \mathrm{g} \mathrm{ml}^{-1}\right)$ and kanamycin $\left(10 \mu \mathrm{g} \mathrm{ml}^{-1}\right)$. The temperature range for growth is $30-70^{\circ} \mathrm{C}$; optimum growth at $50^{\circ} \mathrm{C}$. Facultative anaerobe. DNA G $+\mathrm{C}$ content is $54 \mathrm{~mol} \%$ (by melting temperature). 
The type strain, $\mathrm{AB} 04^{\mathrm{T}} \quad\left(=\mathrm{NCIMB} \quad 13972^{\mathrm{T}}=\mathrm{NCCB}\right.$ $100050^{\mathrm{T}}$ ), was isolated from Ayder Hot Spring, Turkey.

\section{Description of Anoxybacillus kestanbolensis}

sp. nov.

Anoxybacillus kestanbolensis (kes.tan.bo.len'sis. N.L. masc. adj. kestanbolensis pertaining to Kestanbol, a hot spring in the province of Canakkale, Turkey, where the type strain was isolated).

Cells are Gram-positive, motile, spore-forming rods, $0.65 \times 4.75 \mu \mathrm{m}$ in size. Terminal, spherical endospores are formed. Colonies are $1-2.5 \mathrm{~mm}$ in diameter, cream, regular in shape with round edges. Catalase- and oxidase-positive. Starch is hydrolysed but gelatin is not. D-Mannitol, Dglucose, D-fructose, maltose, D-mannose, D-raffinose and $\mathrm{D}$-sucrose are utilized. Nitrate is reduced to nitrite. Urease, indole and $\mathrm{H}_{2} \mathrm{~S}$ are not produced. Growth occurs in the absence of $\mathrm{NaCl}$; optimum growth at $2.5 \% \mathrm{NaCl}$. No growth at concentrations above $4 \% \mathrm{NaCl}$. The $\mathrm{pH}$ range for growth is $6 \cdot 0-10 \cdot 5$; optimum $\mathrm{pH}$ is $7 \cdot 5-8 \cdot 5$. Growth is inhibited in the presence of ampicillin $\left(25 \mu \mathrm{g} \mathrm{ml}^{-1}\right)$, streptomycin sulphate $\left(25 \mu \mathrm{g} \mathrm{ml}^{-1}\right)$, tetracycline $(12 \cdot 5 \mu \mathrm{g}$ $\left.\mathrm{ml}^{-1}\right)$, gentamicin $\left(10 \mu \mathrm{g} \mathrm{ml}^{-1}\right)$ and kanamycin $(10 \mu \mathrm{g}$ $\left.\mathrm{ml}^{-1}\right)$. The temperature range for growth is $40-70^{\circ} \mathrm{C}$; optimum at $50-55{ }^{\circ} \mathrm{C}$. Facultative anaerobe. DNA G+C content is $50 \mathrm{~mol} \%$ (by melting temperature).

The type strain, $\mathrm{K}^{\mathrm{T}}\left(=\mathrm{NCIMB} 13971^{\mathrm{T}}=\mathrm{NCCB} 100051^{\mathrm{T}}\right)$, was isolated from Kestanbol Hot Spring, Turkey.

\section{Acknowledgements}

This work was partly supported by DPT grants 2001K12080010 and KTU 99.111.004.5. A doctoral scholarship to S. D. from The Scientific and Research Council of Turkey is duly acknowledged. We are grateful to Dr F. Sahin for the use of fatty acid analysis equipment and for his assistance.

\section{References}

Belduz, A. O., Dulger, S. \& Demirbag, Z. (2003). Anoxybacillus gonensis sp. nov., a moderately thermophilic, xylose-utilizing, endosporeforming bacterium. Int J Syst Evol Microbiol 53, 1315-1320.

Cowan, S. T. \& Steel, K. J. (1974). Manual for the Identification of Medical Bacteria, 2nd edn. Cambridge: Cambridge University Press.

Felsenstein, J. (1993). PHYLIP (Phylogenetic Inference Package), version 3.6a3. Distributed by the author. Department of Genetics, University of Washington, Seattle, USA.

Pikuta, E., Lysenko, A., Chuvilskaya, N., Mendrock, U., Hippe, H., Suzina, N., Nikitin, D., Osipov, G. \& Laurinavichius, K. (2000). Anoxybacillus pushchinensis gen. nov., sp. nov., a novel anaerobic, alkaliphilic, moderately thermophilic bacterium from manure, and description of Anoxybacillus flavithermus comb. nov. Int J Syst Evol Microbiol 50, 2109-2117.

Pikuta, E., Cleland, D. \& Tang, J. (2003). Aerobic growth of Anoxybacillus pushchinoensis $\mathrm{K}^{\mathrm{T}}$ : emended descriptions of A. pushchinoensis and the genus Anoxybacillus. Int J Syst Evol Microbiol 53, 1561-1562.

Wayne, L. G., Brenner, D. J., Colwell, R. R. \& 9 other authors (1987). International Committee on Systematic Bacteriology. Report of the ad hoc committee on reconciliation of approaches to bacterial systematics. Int J Syst Bacteriol 37, 463-464. 